\title{
Malignant Mediastinal Non- Seminomatous Germ Cell Tumor
}

National Cancer Institute

\section{Source}

National Cancer Institute. Malignant Mediastinal Non-Seminomatous Germ Cell Tumor.

NCl Thesaurus. Code C6439.

An extragonadal non-seminomatous malig nant germ cell tumor that arises from the mediastinum. This category includes embryonal carcinoma, yolk sac tumor, choriocarcinoma, and mixed germ cell tumors. 